\title{
NVMO-congres 2006
}

\section{Juryrapport}

Voor het NVMO-congres 2006 heeft uitgeverij Bohn Stafleu van Loghum opnieuw drie prijzen beschikbaar gesteld. Eén prijs is uitgeloofd voor de beste poster, één voor de beste paper/presentatie en één voor de beste wetenschappelijke paper.

De prijzen waren, per categorie: een bos bloemen (ook al kwam deze wat later), de uitnodiging de poster/paper/ wetenschappelijke paper tot een artikel te bewerken dat in het Tijdschrift voor Medisch Onderwijs gepubliceerd kan worden, een boekenbon van $€ 150$ ter keuze uit de uitgaven van uitgeverij Bohn Stafleu van Loghum, en gratis inschrijving en verblijf bij het volgende NVMO-congres. Deze laatste prijs was nieuw in 2006. De jury bestond uit mw. drs. Kristin Hendrickx (Universiteit van Antwerpen), Ronald van den Bosch (student geneeskunde UMC Utrecht), dr. Lambert Schuwirth (Universiteit Maastricht) en mw. dr. Sanneke Bolhuis (UMC St. Radboud), leden van het wetenschappelijk comité van het NVMO-congres 2006 en dr. Jan van Dalen (redactie Tijdschrift voor Medisch Onderwijs, Universiteit Maastricht) als voorzitter.

De jury heeft eerst alle abstracts verdeeld, zodat vermeden werd dat iemand een oordeel moest geven over een eigen abstract. De jury lette op: originaliteit, relevantie, het overstijgen van lokaal belang en vorm. In gezamenlijk overleg zijn daarna de beste abstracts van posters, papers en wetenschappelijke papers genomineerd. De genomineerde abstracts zijn aan het einde van deze bijdrage opgenomen.

De presentaties van de genomineerde abstracts zijn bezocht en beoordeeld op inhoud, structuur, presenteerstijl, tijdbewaking en discussie. De genomineerde posters zijn bekeken en beoordeeld op mate van uitnodiging, layout, inhoud en boodschap.
De prijs voor de beste poster is gewonnen door: A.S. Littooij (UMC Utrecht) met de poster Semi-arts stage Radiologie in de regio Utrecht: opzet en eerste ervaringen. De jury heeft deze prijswinnaar (met haar medeauteurs J. P.J. van Schaik, T. Weits en H.J. Baarslag) gekozen, omdat de poster uitmuntte in toegankelijkheid. De programma-evaluatie van deze nieuwe stage, waarover in de poster verslag wordt gedaan, is netjes uitgevoerd en helder gerapporteerd. We hopen dit verslag in het Tijdschrift voor Medisch Onderwijs te kunnen publiceren. De prijs voor de beste paper is gewonnen door: F.W. Dekker (LUMC), die met de medeauteurs J.W. de Jong, A. van Hylckama Vlieg, J.W. Schoones en A.J. M. de Craen onderzocht: Hoe evidence-based zijn geneesmiddelenadvertenties in medische tijdschriften? Een onderzoek uitgevoerd door 278 studenten als manier om het belang van kritisch lezen over te brengen. In een heldere, bescheiden presentatie werd gerapporteerd hoe tweedejaars geneeskundestudenten gestimuleerd werden een kritische analyse te geven van de 'onderbouwing' door literatuur die in advertenties voor geneesmiddelen wordt aangegeven. Ook deze auteursgroep is uitgenodigd hun onderzoek om te werken tot een publicatie in het Tijdschrift voor Medisch Onderwijs.

Voor de beste wetenschappelijke paper is de aanmoedigingsprijs gewonnen door M. Penninga, die samen met J.B.M. Kuks en J. Cohen- Schotanus onderzoek verrichtte naar de invloed van toetsvorm (open-of gesloten-boek) op leerstrategie. De helderheid en toegankelijkheid van het abstract was een eerste selectiecriterium dat positief uitviel voor deze onderzoekers. Ten tweede viel op dat de resultaten contra- intuïtief waren, dat wil zeggen dat geslotenboek leren diepgaand leren meer leken te stimuleren dan open-boek toetsen, waarbij de auteurs zorgvuldig hebben gepoogd deze bevindingen 
te verklaren. Tenslotte moet vermeld worden dat dit de derde keer is dat mw. Penninga als eerste of mede-auteur betrokken is bij een prijswinnende presentatie! We hopen ook dit artikel in het Tijdschrift voor Medisch Onderwijs te kunnen publiceren.

Jan van Dalen

Voorzitter jury NVMO-congres 2006

\section{Posters}

Pilotproject 'studentopleiders' ter ondersteuning van het oefenen van technische vaardigheden bij studenten geneeskunde

\section{Aubry}

Probleemstelling: Perkins (2002) en Goodfellow (2001) toonden aan dat 'peerassisted learning' (de begeleiding door medestudenten of hogerejaars studenten) een meerwaarde betekent zowel voor de studentopleider als voor de student die de begeleiding ontvangt. Vaardigheden aanleren is een arbeidsintensief proces: studenten krijgen in kleine groep de kans om, na een demonstratie, de vaardigheid een eerste keer te oefenen onder begeleiding van een docent. Daarna kunnen zij vrijwillig komen oefenen in het vaardigheidscentrum. Ervaring leert dat, naast het aanwezige didactische materiaal op de elektronische leeromgeving, studenten toch nog behoefte hebben aan begeleiding tijdens deze oefensessies. Het aanbod van bijkomende begeleiding is beperkt door het gebrek aan docententijd. Dit gaf aanleiding tot het opstarten van een pilotproject waarbij studentopleiders werden ingezet om studenten van het tweede masterjaar te begeleiden in voorbereiding op de vaardighedentoets. De volgende vragen zijn onderzocht: wat is de perceptie van de studentopleiders en de studenten die begeleid werden over dit project en hoeveel studenten hebben gebruik gemaakt van de begeleiding?

Methode/opzet: Er was een grote interesse en motivatie om deel te nemen aan dit project. Er werden 25 studentopleiders geselecteerd uit het eerste en tweede masterjaar. Zij kregen een diepgaande training in de vaardigheden die ze begeleiden en ze werden opgeleid in onderwijskundige basisvaardigheden om deze vaardigheden te kunnen overbrengen aan medestudenten. De perceptie van de studenten en studentopleiders werd bevraagd aan de hand van een lijst van 13 stellingen met 6 punts-Likertschaal en enkele open vragen.

Resultaten: Elke studentopleider heeft gedurende 6 uren een groep van 8 studenten van het tweede masterjaar begeleid. Van de studenten kon $85 \%(n=221)$ zich vrijwillig inschrijven en heeft dit minstens één keer gedaan. In totaal werden er $50 \%$ bijkomende kansen geboden om gedurende een uur begeleid te worden: er werden 1200 begeleide oefenuren extra geboden. De studentopleiders $(n=22)$ zijn erg enthousiast over hun ervaring. De commentaren zijn unaniem positief: "het is een rijke ervaring waarbij je een unieke kans krijgt om zelf op een geavanceerde manier bij te leren, het is verrijkend om te leren hoe je iemand iets aanleert". Dit zou een meerwaarde kunnen betekenen voor hun toekomstige rol als stagebegeleider. Zij vragen wel een betere vervolging van hun begeleiding in verband met hun competenties.

De helft van de studenten heeft de vragenlijst ingevuld; $90 \%$ van de studenten vond deze sessies noodzakelijk en ervoer een toename van hun competentie; $50 \%$ twijfelde soms of de studentopleiders de vaardigheden op de juiste manier aanleerden. De vaardighedentoets was vergelijkbaar met de toets van vorig jaar: zelfde stations en zelfde beoordelaars. Deze laatsten waren unaniem: met uitzondering van één station scoorden de studenten op alle stations beter dan vorig jaar.

Evaluatie: Dit project zal voortgezet worden maar de studentopleiders zullen meer supervisie krijgen van de docenten. Er zal worden onderzocht in hoever studentopleiders kunnen worden ingezet om de praktijk van BLS (Basic Life Support) te geven aan studenten van het eerste jaar van de bacheloropleiding.

Correspondentieadres:

C. Aubry, KU Leuven, Faculteit geneeskunde, Vaardigheidscentrum O\&N 2, Postbus 324, 3000 Leuven, België, chris.aubry@med.kuleuven.be.

Studenten op stage: voor en nadelen van E-begeleiding

V. de Clercq, B. Koole, E. Witvrouw, A. Derese

Context: Binnen een beroepsgerichte opleiding is ervaringsgericht leren via stage een noodzakelijke component. Gedurende de opleiding Revalidatiewetenschappen en kinesitherapie (fysiotherapie) zijn studenten steeds minder op het opleidingsinstituut aanwezig en brengen ze steeds meer tijd door op de stageplaats. De mentor op de stageplaats speelt een centrale rol in het begeleiden van de studenten ter plaatse en het geven van feedback. Hieruit kan men concluderen dat de sturing van de studenten vanuit het opleidingsinstituut door stagebegeleiders vaak minimaal is. Sommige mentoren zijn onvoldoende opgeleid tot het geven van een kwaliteitsvolle begeleiding. De kennis en attitudes van de mentoren komen niet altijd overeen met deze van de opleiding. Een beperkte beschikbaarheid van de, veelal deeltijds, aanwezige stagebegeleiders leidt tot een bijkomende moeilijkheid voor een persoonlijke doeltreffende benadering van de studenten.

Methode: Een elektronisch systeem werd geïntroduceerd in de opleiding Revalidatiewetenschappen en 
kinesitherapie (fysiotherapie) om flexibele communicatie mogelijk te maken tussen studenten en stagebegeleiders. Dit studentgecentreerde systeem gaf de studenten de mogelijkheid stagedocumenten te verzamelen en online beschikbaar te stellen aan hun stagebegeleiders. Deze konden het elektronische geheel steeds bekijken en op hun beurt direct feedback geven op de verschillende documenten binnen dit geheel.

Resultaten: Door de tijd- en plaatsonafhankelijkheid van het systeem ontstond frequente communicatie tussen studenten en stagebegeleiders. De student ontving bijgevolg tijdens de stageperiode zowel feedback van de externe mentor als van de stagebegeleider, resulterend in een grotere participatie van het opleidingsinstituut tijdens de stage, waarbij men korter op de bal kon spelen tijdens de stages. Het verzorgen van schriftelijke feedback bleek echter niet altijd evident en de stagebegeleiders meldden een gemis aan persoonlijk contact.

Conclusie: Het online communicatiesysteem kan het contact tussen de studenten op de stageplaats en de stagebegeleiders in het opleidingsinstituut bevorderen, resulterend in een extra begeleidingskanaal voor de studenten. Online communicatie werkt kwaliteitsverhogend voor de stagebegeleiding, maar vormt echter geen solitair begeleidingsmiddel. Optimalisering is mogelijk door middel van een goede wisselwerking tussen begeleiding door mentoren op de stageplaats enerzijds en begeleiding via online communicatie en 'life contacten' tussen studenten en stagebegeleiders anderzijds. Opleidingssessies aan stagebegeleiders met betrekking tot het geven van schriftelijke feedback en het onderkennen van probleemsituaties bij studenten zijn aangeraden. Correspondentieadres:

Lic. Veerle De Clercq, Universiteit Gent, Vakgroep Revalidatiewetenschappen en kinesitherapie, Campus Heymans (UZ) 6K3, De Pintelaan 185, B-9000 Gent, België,

VeerleA.DeClercq@UGent.be.

Vinden docenten MeSH een geschikt instrument voor het beschrijven van hun $\mathrm{COO}$ lessen?

F.G. Diepmaat, P.M. Bloemendaal, M. Doets, S. Eggermont, A.J.M. de Man, P.F. Robbé de Vries

Probleemstelling: Het door de Stichting SURF gesubsidieerde project SCALE (Study Coach and Learning Environment), waarin het LUMC, Erasmus MC, UMC St.Radboud en het UMC Utrecht participeren, heeft tot doel een vrij toegankelijke portal (zie: www.medischonderwijs. $n l$ ) te ontwikkelen voor medisch Computer Ondersteund Onderwijs (COO). Elke COO-les is geklasseerd met medisch inhoudelijke, administratieve, onderwijskundige en technische trefwoorden. Voor de medisch inhoudelijke klassering is gebruik gemaakt van de
Medical Subject Headings (MeSH), een trefwoordenlijst van ruim 40.000 termen in een boomstructuur. Er is ook een Nederlandse vertaling beschikbaar. De meeste MeSH-termen zijn niet door docenten -de inhoudelijke experts- toegekend aan de lessen, maar door COO-ontwikkelaars of student-assistenten. Onderzocht wordt of docenten vinden dat MeSHtermen hun COO-lessen correct en voldoende beschrijven.

Methode/Opzet: In de periode maart tot en met september 2006 zijn tien docenten per deelnemende instelling geïnterviewd aan de hand van een vragenlijst. Eerst werd hen gevraagd om de COO-lessen, waarvoor ze zelf de inhoud hebben aangeleverd, te beschrijven met zelf gekozen trefwoorden. Vervolgens werden op papier de in medischonderwijs.nl toegekende MeSH-trefwoorden getoond met de vraag of deze de inhoud van de les goed weergeven en of deze voldoende dekkend zijn voor de inhoud van de les. Tegelijk werd de docent verzocht om aan te geven welke trefwoorden onjuist zijn of nog ontbreken. Tenslotte is gevraagd of een meer globale of juist meer gedetailleerde beschrijving op zijn plaats zou zijn.

Ervaringen: In maart 2006 waren 480 van de in totaal 668 ingevoerde lessen op de portal geklasseerd met gemiddeld 4.04 MeSH-termen per les. De gemiddelde diepte van de toegekende trefwoorden in de $\mathrm{MeSH}$ boom was 4.70 (variërend van 1 tot 9 niveau's onder de MeSHroot). Verreweg de meeste termen die toegekend zijn aan de COO-lessen zijn afkomstig uit de MeSH-tak 'Diseases' (1001 termen), maar ook 'Anatomy' (390), 'Analytical, Diagnostic and Therapeutic Techniques and Equipment' (228) en 'Biological Sciences' (209) zijn favoriet. Termen uit de takken 'Humanities', 'Technology and Food and Beverages' en 'Geographic Locations' zijn niet of nauwelijks gebruikt.

Conclusie: Uit eerste resultaten van dit onderzoek is gebleken dat de door docenten aangegeven trefwoorden in het onderzoek grotendeels overeenkomen met de $\mathrm{MeSH}$-termen die in eerdere instantie in medischonderwijs.nl zijn gekoppeld aan hun COO-lessen. Derhalve lijken docenten tevreden met de toegekende MeSH-termen. Enkele docenten vinden de Nederlandse synoniemen niet helemaal correct.

Correspondentieadres:

F.G. Diepmaat, Erasmus MC, Postbus 2040, 3000 CA Rotterdam,f.diepmaat@erasmusmc.nl.

Samenwerking tussen het skillslab van de Universiteit Maastricht en de Hogeschool Zuyd bij de opleiding tot nurse practitioner

E.M. van Duijnhoven, G. Bours, T. Korsten, M. Verwijnen 
Probleemstelling: In augustus 2005 is aan de Hogeschool Zuyd (HS Zuyd) in Heerlen een nieuwe masteropleiding tot nurse practitioner van start gegaan. Het concept voor deze opleiding werd overgenomen van de Hanze Hogeschool in Groningen. In het kader van de nurse practitioner opleiding dienen de studenten o.a. fysisch-diagnostische vaardigheden aan te leren. De HS Zuyd besloot hiervoor geen eigen vaardigheidsonderwijs te ontwikkelen, maar te evalueren of aansluiting bij de expertise op het gebied van fysisch-diagnostische vaardigheden van de UM mogelijk was. De vraagstelling was of, en zo ja, hoe en in welke vorm, doceren van fysisch-diagnostische vaardigheden aan de studenten van de HS Zuyd op het skillslab in Maastricht zou kunnen plaats vinden.

Methode: In een eerste overleg tussen de samensteller van het curriculum van de HS Zuyd en de aangewezen contactpersoon binnen het skillslab werden op gebied van inhoud van het curriculum en logistieke zaken in gezamenlijk overleg plannen opgesteld. In enkele volgende gezamenlijke besprekingen werden deze plannen verder geconcretiseerd en zo nodig bijgesteld. Door de contactpersoon van het skillslab werden ze schriftelijk ter goedkeuring voorgelegd aan het managementteam. Na goedkeuring kwamen ze ter inzage van alle medewerkers. Uiteindelijk werden de definitieve plannen in een plenaire bespreking met alle skillslabmedewerkers mondeling toegelicht, om een goed draagvlak te scheppen onder alle betrokkenen bij implementatie, uitvoering en ondersteuning van het onderwijs.

Resultaten: Vanaf september 2005 vinden alle fysischdiagnostische trainingen van de HS Zuyd op het skillslab van de UM plaats, direct voorafgaand aan de daarmee samenhangende overige praktische en theoretische lessen in Heerlen. De vaardigheidstrainingen bevatten o.a. fysische diagnostiek van longen, hart- en vaten, buik, en verder KNO, oogheelkunde, bewegingsapparaat, neurologie en gynaecologie. De studenten gebruiken dezelfde leerboeken en krijgen les van dezelfde docenten als de studenten geneeskunde en de inhoud van de trainingen is ook grotendeels conform de inhoud van de overeenkomstige trainingen aan de jongerejaars studenten geneeskunde. Problemen ontstonden met name op het gebied van opbouw van en informatievoorziening over ontkleding en ten aanzien van expliciete eisen voor inroostering. Studentenevaluaties van de trainingen op het skillslab leveren een zeer goede waardering op. Ook de betrokken skillslab-docenten zijn zeer enthousiast over het onderwijs aan de hogeschoolstudenten.

Conclusie: Uitvoering van goed aansluitend vaardigheidsonderwijs voor nurse practitioner studenten van de HS Zuyd door het skillslab van de Universiteit Maastricht is inhoudelijk en logistiek goed mogelijk gebleken. Zowel van studenten als docenten lijken voornamelijk positieve reacties te komen. Ook overige hogescholen zouden aansluiting bij de bestaande expertise in nabijgelegen medische faculteiten dienen te overwegen.

Correspondentieadres:

Dr. E.M. van Duijnhoven, Universiteit Maastricht, Skillslab Toon Hermanssingel 51, 6132 BT Sittard, e.vanduijnhoven@sk.unimaas.nl.

Semi-arts stage Radiologie in de regio Utrecht: opzet en eerste ervaringen

A.S. Littooij, J.P.J. van Schaik, T. Weits, H.J. Baarslag (winnaar posterprijs)

Inleiding: In de nieuwe medische curricula vormt het 6e jaar een koppeling tussen de artsopleiding en de specialistenopleiding. In dit schakeljaar kan de student zich nader profileren en oriënteren op de vervolgopleidingen en krijgt hij, dan semi-arts genoemd, in principe dezelfde verantwoordelijkheid en zelfstandigheid als een beginnend arts-assistent. De semiarts stage radiologie is een keuze-onderdeel en wordt binnen het opleidingscluster aangeboden in het UMCU, Diakonessenhuis Utrecht en Meander Medisch Centrum.

Methode: Om de semi-arts zelfstandig te kunnen laten werken is deze stage gericht op een gedeelte van de radiologie, waar hij/zij speciale interesse voor heeft. Dit interessegebied is gebaseerd op een medische specialisme. De gehele stage duurt 12 weken, onderverdeeld in twee deelstages van 6 weken, elk op een verschillende modaliteit. $\mathrm{Na}$ een gedegen voorbereiding in de eerste week van de deelstage werkt de semi-arts de volgende 5 weken als jongste assistent, onder supervisie van de radiologen.

Om de eerste ervaringen en resultaten te kwantificeren zijn alle deelnemende semi-artsen en betrokken stafleden geënquêteerd.

Resultaten: Deze stage is in het najaar van 2004 gestart. Tot begin mei 2006 hebben in totaal 13 semiartsen de stage doorlopen, waarvan 5 studenten in het UMCU, 4 in het Diakonessenhuis en 4 in Meander Medisch Centrum. Deze 13 studenten hebben de stage geëvalueerd middels een enquête. Zes van de 13 studenten $(46 \%)$ gaven na afloop aan een opleidingsplaats radiologie te ambiëren. Twee daarvan zijn intussen aangenomen binnen het Utrechtse opleidingscluster. De andere aangegeven voorkeuren voor medische specialisaties waren kindergeneeskunde, orthopedie, urologie, eerste hulp geneeskunde, huisartsgeneeskunde en interne geneeskunde. De resultaten van de eerste evaluaties lieten een zeer positieve waardering van de stage zien, het gemiddelde cijfer op een schaal van 0-10 bedroeg een 8,9 (SD 0,7). De semi-artsen verwachtten veel profijt te hebben van deze stage. 
Door een gedegen opzet van de stage bleek de stage op de drie lokaties organisatorisch haalbaar en vonden de betrokken radiologen het werken met de stagisten inspirerend. De begeleiders ondervonden dat de semi-arts daadwerkelijk op een adequaat niveau werken, gezien de kwantiteit en kwaliteit van de beoordeelde onderzoeken.

Conclusie: De semi-arts stage radiologie is een nieuw fenomeen in Nederland. Er is praktisch geen ervaring met studenten die zelf radiologische onderzoeken beoordelen en verslaan. Niet alleen de studenten die de radiologie ambiëren maar ook studenten die een ander medischspecialistische opleiding willen gaan volgen melden zich aan. Uit de enquête blijkt dat met deze opzet de semi-artsen daadwerkelijk meedraaien als jongste assistent en naar oordeel van de betrokken stafleden ook op dat niveau kunnen functioneren.

Correspondentieadres:

Drs. A.S. Littooij, UMC Utrecht, afdeling Radiologie Heidelberglaan 100, Huispostnummer E01.132, 3584 CX Utrecht,a.littooij@azu.nl.

Het ICF-model als instrument voor onderwijs in de revalidatiegeneeskunde en artsopleiding

\section{G.M. Rommers, W.G.M. Bakx}

Probleemstelling: Het ICF model (International Classification of Function, Disability and Health) wordt door de World Health Organisation (WHO) gepropageerd als instrument voor analyse van het functioneren van de patiënt. Diverse aspecten van het ICF model zijn herkenbaar als elementen in het raamplan opleiding basisarts.

In de revalidatiegeneeskunde wordt dit model als standaard gebruikt voor inventarisatie en analyse van functioneren. Is het daarmee ook goed bruikbaar als onderwijsinstrument?

Methode: Bij bijdragen van de revalidatiegeneeskunde in blokonderwijs, praktijkstage of co-schap wordt een introductie gegeven in het ICF model waarbij voorbeelden worden gegeven van aan de hand van verschillende aandoeningen zoals: diabetes, CVA, amputatie en dwarslaesie. Door variatie van de factoren kan een eenvoudige of moeilijke casus worden samengesteld direct verbonden met de dagelijkse praktijk.

Opzet: Aan de hand van patiëntendemonstraties, (poli)kliniekpatiënten of casusbeschrijvingen worden voorbeelden aangedragen die ingevoegd kunnen worden in het bovenstaande schema van functies, activiteiten en participatie. Externe factoren (bv toegankelijkheid gebouw, vervoer of wetgeving) en persoonlijke factoren (bv persoonlijkheidsfacoren, copingstijl of motivatie) worden eveneens toegevoegd. In de medische statusvoering worden de ICF onderdelen voorgedrukt op het statusformulier aangeboden. In verslaglegging van bevindingen in de brief aan de huisarts wordt het model gebruikt voor informatie en evaluatie. Door gebruik van het model kunnen verschillende schakels van het functioneren zichtbaar worden gemaakt en besproken. Aspecten zoals psychosociale factoren of chronische aandoeningen kunnen via het ICF-model goed worden overgebracht aan de student. Het wordt op die manier duidelijk waarom deze aspecten mede tot het takenpakket van iedere arts behoren.

Ervaringen: Studenten kunnen het model eenvoudig toepassen en krijgen op deze manier snel een volledig beeld van de relatie tussen aandoeningen en het functioneren van de patiënt. De omschakeling van orgaangericht denken naar denken in termen van functioneren met aandoeningen wordt door de studenten snel gemaakt. Het model kan toegepast worden op een groot aantal verschillende aandoeningen is mogelijk. Ook andere specialismen kunnen met het model het functioneren van de patiënt snel in kaart brengen. Verslaglegging t.a.v functioneren wordt bekort en blijft overzichtelijk.

Samenvatting: Het ICF model als inventarisatieinstrument voor functioneren met verschillende aandoeningen geeft een goed model om studenten en AIOS eenvoudig inzicht te geven in de relatie tussen aandoening en functioneren in de medisch-maatschappelijke context. Het biedt een groot aantal mogelijkheden om binnen het onderwijs verschillende diagnosen en het functioneren ermee inzichtelijk en toepasbaar te maken. Correspondentieadres:

Dr. G.M. Rommers, Centrum voor Revalidatie UMCG/ Revalidatiegeneeskunde, Postbus 30.001, 9700 RB Groningen,g.m.rommers@rev.umcg.nl.

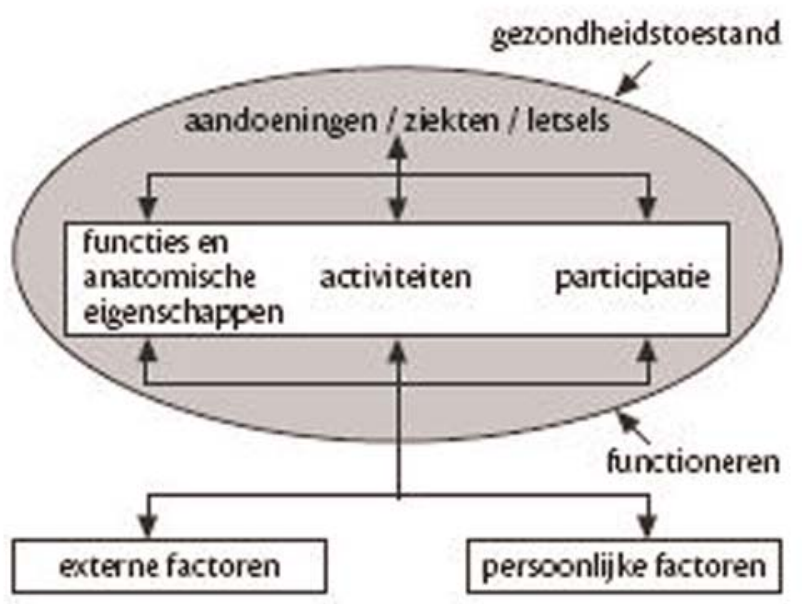

Figuur 1 Caption 1: ICF model. 
Inventarisatie van het onderwijs in elementaire eerste hulpverlening aan de medische faculteiten in Nederland

\section{K.D. Hekkert, E.C.T.H. Tan, A.B. van Vugt, J. Biert}

Probleemstelling: Van (aankomende) artsen wordt verwacht dat zij de eerste hulpverlening beheersen. Volgens de eindtermen van de artsopleiding beschreven in het Raamplan 1994, wordt van de (aankomende) arts verwacht dat hij eerste hulp moet kunnen verlenen op minimaal het niveau zoals omschreven in het Oranje Kruis Boekje. In het 'Raamplan 2001, de bijgestelde eindtermen van de artsopleiding' wordt gesteld dat "de arts in staat is basale eerste hulp te verlenen zoals omschreven in de Advanced Trauma Life Support". Het onderwijs aan de medische faculteiten in Nederland moet voldoen aan de eindtermen beschreven in het Raamplan voor de artsopleiding, hetgeen inmiddels wettelijk is vastgesteld.

Vraagstelling: Voldoet het onderwijs in de artsopleiding in Nederland aan de eindtermen zoals gesteld in het Raamplan van de artsopleiding, betreffende elementaire eerste hulpverlening en basic life support?

Methode: De onderwijsverantwoordelijken inzake eerste hulpverlening en basic life support van alle medische faculteiten in Nederland werden geïnterviewd over praktische vormgeving, inhoud en mening over het onderwijs. De inhoud werd verdeeld in vaardigheden en ziektebeelden conform het Raamplan. Studenten Geneeskunde in Nederland werden geënquêteerd middels een online enquête. Hierin werd gevraagd naar tevredenheid over het eerste hulp onderwijs en niveau waarop men verschillende eerste hulp vaardigheden en ziektebeelden beheerst.

Resultaten: Respons onderwijsverantwoordelijken eerste hulpverlening was $100 \%$. Zeven van de acht universiteiten besteden aandacht in het curriculum aan elementaire eerste hulp verlening en basic life support onderwijs. De onderwijsverantwoordelijken gaven aan tevreden te zijn over het onderwijs en noemden geen grote belemmeringen voor de uitvoering. Gemiddeld werd echter voor slechts $69 \%$ van de vaardigheden het niveau van het Raamplan gehaald, en voor $38 \%$ van de ziektebeelden. Voor de vaardigheden haalde het VUmc het hoogste percentage, voor de ziektebeelden het Erasmus MC. In het curriculum wordt te weinig aandacht besteed aan het verwijderen van een corpus alienum, maskerballon beademing, het gebruik van een automatische externe defibrillator, de snelle kantelmethode, de 'regel van 9' bij brandwonden en het aanleggen van verbanden en een driekante doek. Duizend acht en zeventig studenten geneeskunde vulden de online enquête in. De gemiddelde student haalde $65 \%$ van de vaardigheden op het niveau van het Raamplan, en $33 \%$ van de ziektebeelden. Studenten van het Erasmus MC haalden het hoogste gemiddelde niveau voor de vaardigheden, studenten van het UMCN voor de ziektebeelden. Gemiddeld gaf $51 \%$ van de studenten aan tevreden te zijn over het onderwijs in elementaire eerste hulp verlening en basic life support. Het minst tevreden is men over de hoeveelheid onderwijs. Over het algemeen waren UMCN studenten het meest tevreden.

Conclusie: Het onderwijs in de artsopleiding in Nederland en het niveau van de studenten voldoet onvoldoende aan de eindtermen van het Raamplan, zoals wettelijk is vastgesteld. Slechts de helft van de studenten is tevreden over het onderwijs in elementaire eerste hulpverlening en basic life support. Naar onze mening dient er een gecertificeerde spoedeisende hulp cursus gegeven te worden, waarin zowel elementaire eerste hulp als basic life support vaardigheden aan bod komen in de artsopleiding. Deze cursus en regelmatige herhalingslessen zouden een verplicht karakter moeten hebben ten tijde van de artsopleiding.

Correspondentieadres:

Edward C.T.H. Tan, afdeling Heelkunde, sectie Traumatologie,UMC St Radboud, Huispost 690, Postbus 9101, 6500HB Nijmegen,E.Tan@chir.umcn.nl.

Het gebruik van 'Entrustable Professional Activities' bij de concretisering van competenties naar de opleidingspraktijk

\section{Wijnen-Meijer, Th.J. ten Cate}

Probleemstelling: Op welke wijze kunnen CanMEDScompetenties worden geconcretiseerd voor de opleidingspraktijk?

Inleiding en achtergrond: Er wordt momenteel door verschillende wetenschappelijke verenigingen gewerkt aan de modernisering van de medische vervolgopleidingen. Uitgangspunt daarbij is dat de opleidingen competentiegericht opgezet moeten worden, waarbij in Nederland de CanMEDS-competenties het kader vormen voor de vernieuwing van de medische vervolgopleidingen. Een belangrijk kenmerk van competentiegericht onderwijs is dat de beroepspraktijk het uitgangspunt is van de opleiding. Een probleem daarbij is echter dat de CanMEDS-competenties redelijk abstract geformuleerd zijn en niet gekoppeld aan concrete beroepssituaties. Om specialistenopleidingen competentiegericht te kunnen opzetten, moet dus op een of andere manier de koppeling gemaakt worden tussen CanMEDS en de dagelijkse praktijk.

Methode: Er is daarom een instrument ontwikkeld om de kritische beroepsactiviteiten in kaart te brengen. Dit instrument betreft de zogenaamde Entrustable Professional Activities (EPA's). Een Entrustable Professional 
Activity is een kritische beroepsactiviteit die men kan 'toevertrouwen' aan een assistent in opleiding op het moment dat voldoende competentie is verworven om de activiteit zelfstandig uit te voeren. Vóór dat moment is supervisie nodig, daarna niet. De assistent is een drempelwaarde van competentie gepasseerd. De assistent die alle bij het specialisme behorende EPA's zelfstandig kan uitvoeren, heeft het eindniveau van de opleiding bereikt.

Bij de ontwikkeling van de opleidingsplannen van een aantal medische vervolgopleidingen, is gestart met het formuleren van Entrustable Professional Activities om de beroepspraktijk te beschrijven. Deze EPA's vormden de basis voor de ontwikkeling van het curriculum en de toetsing.

Conclusie: De geformuleerde EPA's blijken een goed uitgangspunt te zijn voor de ontwikkeling van de curricula voor competentiegerichte medische vervolgopleidingen. De EPA's bieden houvast bij de uitwerking van zowel de inhoud als de vormgeving van de opleiding als de toetsing.

Het concept van Entrustable Professional Activities is bruikbaar voor de ontwikkeling van een competentiegericht curriculum.

In deze posterpresentatie wordt, aan de hand van een aantal praktijkvoorbeelden, uitgelegd hoe EPA's geformuleerd kunnen worden en op welke manier ze gebruikt kunnen worden bij curriculumontwikkeling en toetsing. Correspondentieadres:

Drs. M. Wijnen-Meijer, UMC Utrecht, Expertisecentrum voor onderwijs en opl., Huispost HB 4.05, Postbus 85500,3508GAUtrecht,m.wijnen-meijer@umcutrecht. $n l$.

\section{Papers}

Hoe evidence-based zijn geneesmiddelenadvertenties in medische tijdschriften? Een onderzoek uitgevoerd door 278 studenten als manier om het belang van kritisch lezen over te brengen

F.W. Dekker, J.W. de Jong, A. van Hylckama Vlieg, J. W. Schoones, A.J.M. de Craen (winnaar paperprijs)

Probleemstelling: In het kader van hun wetenschappelijke vorming is het van belang dat studenten geneeskunde niet alleen leren hoe ze artikelen kritisch kunnen lezen (critical appraisal), maar ook het belang ervan leren onderkennen. Dat laatste is vaak moeilijk over te brengen zonder studenten het zelf te laten ervaren. Wij vroegen ons af of het mogelijk is een grote groep studenten binnen een regulier onderwijsblok (3 weken) onderzoek te laten doen waaruit het belang van kritisch lezen voor henzelf naar voren komt.
Methode: Studenten geneeskunde $(\mathrm{N}=278)$ werden in het 2e jaars blok Wetenschappelijke Vorming aangezet tot het met elkaar doen van een onderzoek naar hoe evidencebased geneesmiddelenadvertenties zijn in grote medische tijdschriften. Hiertoe werden tevoren in zes tijdschriften (Am J Med, Arch Int Med, BMJ, Lancet, JAMA, NEJM) in anderhalve jaargang 189 verschillende farmaceutische advertenties geselecteerd. Hierin stonden 638 claims over effectiviteit en veiligheid van geneesmiddelen die met een referentie werden onderbouwd; 161 van deze referenties bleken gepubliceerde en vindbare verschillende trials (RCT's) te betreffen. Elke student kreeg tijdens het blok random twee van deze RCT's als PDF uitgedeeld. Na een werkgroep-training beoordeelden studenten de kwaliteit van de RCT en de toepasbaarheid op de claim uit de advertentie op een gestandaardiseerd web-based formulier (Chalmers-score). Resultaten werden op een afsluitend college inhoudelijk teruggekoppeld. Direct na afloop van het tentamen werd een enquête afgenomen. Daarnaast werd een panelgesprek gehouden om verbeterpunten in de opzet en de organisatie te bespreken.

Resultaten: De door de studenten toegekende gemiddelde Chalmers-score (maximale range 0-9 punten) was 5.9 (SD 1.4). Met maximaal vier beoordelende studenten per RCT was het verschil tussen de hoogste en de laagste Chalmers- score in $83 \%$ van de RCT's niet meer dan drie punten. Volgens de studenten vormden $54 \%$ van de RCT's door kwaliteit of toepasbaarheid onvoldoende onderbouwing voor de claim uit de advertentie. Uit de enquête aan het eind van het blok bleek dat de studenten van mening waren dat deze onderwijsvorm in belangrijke mate had bijgedragen aan hun vaardigheid in het kritisch lezen $(81 \%)$, en aan hun wetenschappelijke vorming in het algemeen (71\%). Uit het panelgesprek kwam het beoordelen van artikelen als sterk punt naar voren, gesuggereerd werd nog een extra oefening hierover op te nemen.

Conclusie: Farmaceutische advertenties in medische tijdschriften blijken vaak onvoldoende 'evidence based'. De overeenstemming over de score gaf aan dat studenten de artikelen serieus hebben beoordeeld. Het zelf doen van een dergelijk onderzoek blijkt (1) uitvoerbaar in een 3weeks blok, (2) wetenschappelijk verantwoorde resultaten op te leveren, en (3) studenten het belang van (onderwijs in) kritisch lezen naar eigen zeggen duidelijk te maken.

Correspondentieadres:

Dr. F.W. Dekker, Leids Universitair Medisch Centrum, Klinische Epidemiologie, Postbus 9600, 2300 RC Leiden, f.w.dekker@lumc.nl.

Transfer naar de werkplek van de cursus 'Opleiden in de Klinische Praktijk'

C.R.M.G. Fluit, S. Bolhuis 
Probleemstelling: Het begeleiden van (co-)assistenten is complex en stelt hoge eisen aan docenten, die zich tevens voor de taak gesteld zien adequate patiëntenzorg en opleiden te integreren. Om docenten hierbij te ondersteunen heeft het UMC St Radboud te Nijmegen o.a. de cursus 'Opleiden in de klinische praktijk' (OKP) ontwikkeld. Hierin leren klinisch docenten de benodigde vaardigheden (zoals feedback geven, beoordelen, status nabespreken en hanteren rolmodel). Ondanks enthousiasme bij de deelnemers blijkt transfer van het geleerde naar de praktijk moeizaam. De vraag is daarom welke factoren het toepassen van het geleerde in de dagelijkse praktijk (transfer) bevorderen dan wel belemmeren.

Methode: Deelnemers formuleren aan het eind van de cursus hun voornemens ten aanzien van het begeleiden van (co-)assistenten. Na 6 tot 12 maanden ontvangen zij een vragenlijst (posttest), waarop deelnemrs aangeven in hoeverre de voornemens gerealiseerd zijn en welke factoren hierbij een remmende of juist stimulerende rol hebben gespeeld.

Voor dit onderzoek zijn gegevens van deelnemers die in 2003 en 2004 een van de cursussen hebben gevolgd, geanalyseerd. In totaal zijn 100 personen betrokken bij het onderzoek. De respons bedroeg $57 \%$. Van de nonresponders heeft $33 \%$ niet gereageerd, ondanks twee reminders, $6 \%$ kon niet meer bereikt worden, $4 \%$ had geen tijd, geen interesse, of kon door persoonlijke omstandigheden niet meer reageren. De genoemde voornemens én de remmende en stimulerende factoren die door de deelnemers zijn genoemd zijn geanalyseerd, gecodeerd en ingedeeld in een aantal hoofdcategoriën. Vervolgens is nagegaan hoe vaak voornemens wel, niet of deels zijn gelukt en welke factoren hierbij een rol hebben gespeeld.

Resultaten: De onderzoeksgroep bestond uit 7 artsassistenten en 93 medisch specialisten, afkomstig uit 10 specialismen. Opleiders gaven aan dat transfer van het geleerde in de cursus naar de praktijk wordt beïnvloed door team-, individu-, student- en organisatiegerelateerde factoren. Eigen inzet en steun van mede-opleiders worden relatief vaak genoemd als stimulerende factoren. Als 'remmende' factoren worden een gebrek aan steun van het team, tijdsdruk en de eigen onervarenheid met opleiden vooral genoemd. Een deel van de respondenten geeft aan dat met name team- en organisatiegerelateerde factoren het uitvoeren van veranderingen bemoeilijken, en dat dit soms leidt tot terugval in oude routines. Desondanks heeft de cursus bij een deel geleid tot veranderingen in het begeleiden van studenten (o.a. meer tijd voor onderwijs, meer feedback, meer observatie).

Conclusie: Scholing van begeleiders en opleiders van (co-)assistenten kan leiden tot veranderingen. Het is echter belangrijk om een goed beeld te krijgen van belemmerende en bevorderende factoren voor transfer naar de praktijk. Op basis hiervan kunnen aanbevelingen gedaan worden die ertoe bijdragen dat voorgenomen activiteiten m.b.t. het (co-)assistentenonderwijs ook daadwerkelijk gerealiseerd worden, zoals het meer opleiden in teamverband, opleiden op locatie en follow-up begeleiding op de werkplek zelf.

Correspondentieadres:

Drs. C.R.M.G. Fluit, UMC St Radboud, KOMO, 306 OWI/KOMO, Postbus 9101, 6500 HB Nijmegen, c.fluit@owi.umcn.nl.

Evaluatie van de introductie van zelfwerkzaamheid met DiViDU, simulatiepatiënten en peer-feedback in het tweedejaars communicatie onderwijs in het AMC

\section{R.L. Hulsman, N.P. de Graaf, M. Fabriek}

Probleemstelling: Het AMC heeft in 2005- 2006 een nieuw tweedejaars programma geïntroduceerd voor medische gespreksvaardigheden met als kernelementen: geïndividualiseerd, zelfsturend leren; oefenen met simulatiepatiënten; feedback van simulatiepatiënten, docenten en medestudenten; ICT inzet bij professionele ontwikkeling; aanzet tot portfolio ontwikkeling. De tweedejaars oefenen in het anamnese gesprek het uitvragen van het hulpvraagspoor en het diagnostisch spoor gebruikmakend van de verschillende vaardigheden van actief luisteren. In het nieuwe programma oefenden alle 325 tweedejaars met een simulatiepatiënt. De 24 practicumgroepen van ca. 15 studenten werden verdeeld in drietallen. In drie cycli deed telkens één student daarvan tijdens een simulatiepracticum een gesprek dat via een webcam en Windows Movie Maker op de UvA streaming video server werd geplaatst.

DiViDU is een web-applicatie waarmee ieder drietal zelfstandig, online, interactief hun eigen video's kon bekijken, kritische momenten markeren, en analyseren op goede en verbeterbare punten.

Tijdens een evaluatiepracticum presenteerden ze hun analyse aan de groep van 15 , onder begeleiding van een docent. Daarna begon de volgende cyclus. Middels een enquête zijn de ervaringen van studenten en docenten met de verschillende onderdelen van de nieuwe onderwijsformule geëvalueerd.

Methode: De studentvragenlijst (50 vragen) en de docentenvragenlijst (20 vragen) bevragen o.a. logistieke en inhoudelijke aspecten van het oefenen met simulatiepatiënten; feedback ontvangen van simulatiepatiënten, medestudenten en docenten; met DiViDU werken en de gespreksanalyse presenteren.

Resultaten: Enquêtes zijn ingevuld door 291 (90\%) studenten en $14(100 \%)$ docenten. De studenten waren zeer gemotiveerd voor het oefenen met 
simulatiepatiënten (95\%), 75\% vond het leerzaam, 73\% zou graag minimaal drie keer oefenen per jaar. Een meerderheid waardeerde de feedback van docent $(87 \%)$, simulatiepatiënt (76\%), en groepsgenoten $(62 \%)$; samenwerken in drietallen $(78 \%)$, presenteren van de gespreksanalyse $(66 \%)$. De studenten waren kritisch over DiViDU: hoewel $83 \%$ het leerzaam vond hun eigen video terug te zien vond slechts $25 \%$ het handig om videofragmenten te markeren en van commentaar te voorzien. Van de docenten vond $57 \%$ de gesprekken van inhoudelijk goede kwaliteit. De presentaties werden van belang geacht (86\%), maar slechts $44 \%$ vond ze van inhoudelijk goede kwaliteit. Docenten hechten veel belang aan feedback van docent $(93 \%)$ en simulatiepatiënt $(79 \%)$ en vinden peer-feedback belangrijker $(86 \%)$ dan de studenten zelf. Ook docenten zijn terughoudend over het nut van DiViDU: slechts 50\% vond het markeren en becommentariëren van videofragmenten handig.

Conclusie: Studenten vragen om meer oefening met simulatiepatiënten. Over de kwaliteit van de presentaties van de gespreksanalyses waren de docenten niet erg tevreden. De inzet in het onderwijs van DiViDU, dat dient ter voorbereiding van de presentatie, moet worden verbeterd. In het volgende studiejaar zullen de DiViDU opdrachten minder inzoomen op details en zich meer richten op gobale doelen in het gesprek.

Correspondentieadres:

Dr. R.L. Hulsman, Academisch Medisch Centrum, Medische Psychologie, Postbus 22660, 1100 DD Amsterdam r.1.hulsman@amc.uva.nl.

Diversiteitonderwijs in de huisartsopleiding: competenties, ervaren ondersteuning en arbeidssatisfactie

\section{J. de Jong, M.R.M. Visser, M. Wieringa-de Waard}

Probleemstelling: Huisartsen zien veel patiënten uit andere landen en culturen. Vanuit de huisartsopleiding werd de behoefte gevoeld om hierover meer onderwijs aan te bieden. Deze behoefte werd gestaafd door cijfers van recent uitgevoerd Nivel onderzoek: $43 \%$ van de aios van huisartsopleiding van het AMC, vindt dat het onderwijs over 'allochtonen' onvoldoende aan bod komt. In een systematische review uit 2005 wordt geconcludeerd dat culturele competentie training een veelbelovende strategie is om bij professionals attitude, vaardigheden en patiëntenwaardering te verbeteren.

Gezien de vele aspecten van de multi-etnische zorg, is gekozen voor een geïntegreerde aanpak: binnen meerdere modules en lijnen worden de verschillende kanten van het onderwerp belicht. Naast het vergroten van competenties aangaande multi-etnische zorgverlening, zal dit naar verwachting ook de arbeidssatisfactie positief beïnvloeden. In het cohort 2005 is gestart met een nieuw curriculum waarin er structurele aandacht is voor 'diversiteitonderwijs'. In dit onderzoek willen wij nagaan hoe eerstejaars aios huisartsgeneeskunde het diversiteitonderwijs ervaren in termen van competentie, ondersteuning door en behoefte aan onderwijs, en arbeidssatisfactie en welke competenties het meest bijdragen aan werkplezier.

Methode: Eind april 2006 zijn tijdens een onderwijsdag bij alle aanwezige eerstejaars aios vragenlijsten afgenomen $(n=67)$. Gevraagd werd naar de mate van competentie, ondersteuning door onderwijs en behoefte aan meer onderwijs op zeven deelgebieden. Tevens werd gevraagd hoe plezierig en hoe belastend (arbeidssatisfactie) het werken met allochtonen in het algemeen werd gevonden. Antwoorden konden worden gegeven op 6punts schalen (1-6). Met een Anova voor herhaalde metingen werden verschillen in competenties tussen deelgebieden getoetst en met een lineaire regressie werd bepaald welke competenties het meest voorspellend waren voor het werkplezier. De Anova voor herhaalde metingen werd tevens uitgevoerd voor onderwijsondersteuning en voor onderwijsbehoefte.

Resultaten: Aios scoren gemiddeld over de zeven gebieden een 3.47 op competenties, 2.61 op ondersteuning, een 3.79 onderwijsbehoefte. Het meest competent voelt men zich in het omgaan met de taalbarrière, en het minst competent in praktijkorganisatie $(\mathrm{F}(6)=7.586$, $\mathrm{p}=.000$ ). De ervaren ondersteuning was het hoogst voor het verschil in risicofactoren, en het laagst voor praktijkorganisatie $(\mathrm{F}(6)=4.250, \mathrm{p}=.001)$. Er werden geen significante verschillen gevonden in onderwijsbehoeften voor de deelgebieden. Aios vonden Multi-etnische zorg plezierig $(\mathrm{M}=4.01)$ en slechts matig belastend $(\mathrm{M}=3.53)$. De competentie die het meest bijdroeg aan het werkplezier was het omgaan met sociale problematiek $(\mathrm{R} 2=.154$, Beta $=0.392, \mathrm{p}=.002)$.

Conclusie en implicaties voor de praktijk: $\mathrm{Na}$ een half jaar diversiteitsonderwijs voelen de aios zich redelijk competent maar nog niet erg gesteund door het onderwijs. Op alle deelgebieden is meer onderwijsondersteuning gewenst. Het onlangs vernieuwde diversiteitsonderwijs zal voorlopig in zijn huidige vorm worden voortgezet. $\mathrm{Na}$ een jaar vindt opnieuw een evaluatie plaats.

Correspondentieadres:

Drs. J. de Jong, AMC-UvA, Huisartsgeneeskunde, Meibergdreef 15, 1105 AZ Amsterdam, JipdeJong@amc.uva.nl.

Evaluatie van de opleiding anesthesiologie in het AMC: AIOS beoordelen stafleden

M.J.M.H. Lombarts, M.J.L. Bucx, I. Rupp, W. Schlack 
Doel: Het ontwikkelen en testen van een instrument voor evaluatie van de opleiderskwaliteiten van de stafleden anesthesiologie. Feedback aan stafleden dient ter ondersteuning van de verbetering van hun opleiderskwaliteiten en de kwaliteit van de opleiding in het AMC.

Methode: Een werkgroep werd geïnstalleerd bestaande uit 2 stafleden anesthesiologie, 2 AIOS en een adviseur kwaliteitszorg. Een literatuurstudie werd uitgevoerd ter inventarisatie van beschikbare evaluatiemodellen. Op basis hiervan werd besloten een AMCeigen evaluatieformulier te ontwikkelen, uitgaande van de Stanford Faculty Development Program 26 (SFDP $26)$ vragenlijst. De werkgroep bereikte consensus over de in het evaluatieformulier op te nemen opleidingsaspecten en bijbehorende items. Het formulier werd becommentarieerd en goedgekeurd door de stafleden en (separaat) de AIOS. Het formulier werd elektronisch beschikbaar gemaakt. AIOS die minstens 6 maanden in opleiding waren, werden uitgenodigd stafleden te evalueren; evaluatie was vrijwillig en anoniem. AIOS hadden voor de evaluaties ca. 4 weken de tijd. De resultaten van de totale groep van stafleden werden in een plenaire bijeenkomst van stafleden en AIOS gepresenteerd en besproken. Stafleden kregen de eigen scores per interne post toegestuurd. Van hen wordt verwacht dat ze de feedback aanwenden om hun eigen functioneren verder te verbeteren. Afdelingshoofd noch opleider hebben het eerste jaar inzage in de individuele resultaten. Een onafhankelijke coach was beschikbaar voor stafleden die behoefte hadden aan bespreking van de eigen resultaten. Psychometrische analyse van het instrument werd uitgevoerd met behulp van explorerende factoranalyse enbetrouwbaarheidsanalyse.

\section{Resultaten:}

1. Het ontwikkelde evaluatieformulier bestond uit 24 items verdeeld over 6 opleidingaspecten die gescoord werden op een 5 punts Likertschaal en 2 samenvattende items. AIOS konden aangeven als een item niet beoordeeld kon worden. Er was ruimte voor vrije tekst onderaan het formulier.

2. 21 van de 24 AIOS participeerden in de evaluatie, 13 vrouwen en 8 mannen. Geslacht maakte geen verschil in de beoordeling van stafleden. 'Opleidingsjaar' en 'beoordeling van opleidings-kwaliteiten van stafleden' zijn negatief gecorreleerd op bijna alle aspecten.

3. In totaal werden 423 evaluatieformulieren ingevuld voor 39 stafleden. Gemiddeld werden per AIOS 20,1 evaluatieformulieren ingevuld. Een staflid werd gemiddeld door 10,8 AIOS geëvalueerd.

4. Factoranalyse leidde tot reductie en hergroepering van de opleidingsaspecten uit de SFDP 26: opleidingsklimaat, bejegening, communicatie over leerdoelen, toetsing en feedback. De betrouwbaarheid van de schalen was groot: Cronbach's · varieerde tussen 0,85 $-0,95(\mathrm{P}<0,05)$.

5. De opleiderskwaliteiten van de AMC stafleden anesthesiologie werden in het algemeen positief beoordeeld. Op een schaal van 1 (minimum score) tot 5 (max) werden de volgende groepsresultaten gevonden voor de onderscheidende opleidingsaspecten (gemiddelde; SD): opleidingsklimaat $(3,63 \mathrm{SD} 0,67)$; bejegening $(4,07$ SD 0,69$)$ communicatie over leerdoelen $(3,41$ SD 0,81); toetsing (3,76 SD 0,77); feedback $(3,86$ SD 0,68$)$.

Conclusies: Een bruikbaar, valide en betrouwbaar evaluatieformulier is thans beschikbaar voor feedback aan stafleden anesthesiologie over hun opleiderskwaliteiten. Correspondentieadres:

Dr. M.J.M.H. Lombarts, Academisch Medisch Centrum, Soc. Geneeskunde, Meibergdreef 9, 1000 DD Amsterdam,k.lombarts@hetnet.nl.

Een registratieformulier als hulpmiddel voor het aanleren van seksespecifieke aandachtspunten

W. van der Minne, P. Dielissen, P. Verdonk, T. LagroJanssen

Probleemstelling: Rekening houden met seksespecifieke aspecten van patiënt en ziekte verhoogt de kwaliteit van zorg. Toch is sekse/gender een blinde vlek in het medisch onderwijs en ook in de ontwikkeling van standaarden.

Doel: Het aanleren van professioneel gedrag ten aanzien van seksespecifieke aspecten bij de NHG-standaarden angina pectoris, depressie en incontinentie voor urine.

Methode: Op basis van een literatuuronderzoek met een speciaal seksefilter werden evidence based seksespecifieke aanbevelingen geformuleerd bij drie NHG-standaarden depressie, pijn op de borst en urineincontinentie. Met behulp van een trainingsprogramma zijn negen derdejaars huisartsen in opleiding (AIO's) samen met hun huisartsopleiders (HAO's) tav deze seksespecifieke aanbevelingen geschoold. Om het leereffect te vergroten is een registratieformulier ontworpen dat het toepassen van deze aanbevelingen na ieder consult betreffende de drie standaarden vastlegt. Herhaald nabespreking aan de hand van de registratieformulieren moet bewerkstelligen dat op lange termijn aandacht voor deze thema's beklijft. Daarbij werd ruimte ingebouwd voor het bespreken van de leereffecten en reflectie op belemmeringen.

Resultaten: De huisartsen in opleiding en huisartsopleiders hebben honderd registratieformulieren ingeleverd. 39 formulieren betreffende angina pectoris, 40 depressie en 21 over patiënten met incontinentie voor urine. Wat incontinentie betreft blijkt de verdeling erg scheef. De helft van de artsen hebben geen formulieren 
ingeleverd. Het herkennen van de atypische presentatie van angina pectoris is in 39 nabesprekingen aan bod gekomen. Bij 19 van de 30 vrouwen was pijn in de borst was niet gerelateerd aan inspanning. In de nabesprekingen werd de atypische AP en de vraag in hoeverre atypische verschijnselen toch alarmerend zijn besproken. Een van de aanbevelingen bij depressie is dat gevraagd moet worden naar sexueel misbruik of geweld in de voorgeschiedenis. In 12 formulieren is geantwoord dat er actief naar gevraagd is, 16 keer is toegelicht waarom er niet naar is gevraagd en welke belemmeringen ervaren zijn. Nabespreking aan de hand van de formulieren heeft HAO's en AIO's geholpen geweld bijzondere aandacht te geven. In de evaluatie bespreking na de training geven de AIO's aan dat ze dit onderwerp gemakkelijker aan de orde durven stellen in een gesprek.

Conclusie: Het tijdelijk gebruik maken van een registratieformulier met aan te leren aandachtspunten ten aanzien van de consultvoering vergroot de noodzakelijke aandacht voor seksespecifieke aspecten. Daarbij worden de positieve ervaringen bekrachtigd en belemmeringen bespreekbaar gemaakt. Voorwaarden zijn dat het onderwerp praktijkrelevant is, het formulier beknopt en er voldoende tijd beschikbaar is tijdens de nabesprekingen. Correspondentieadres:

Drs. H.W. van der Minne, UMC St. Radboud Nijmegen Vrouwenstudies in medische wetenschap, hwvanderminne@planet.nl.

Effecten van compensatie benaderingen na de Borderline Regressie Normeringmethode van een tandheelkundige OSCE

M.E. Schoonheim-Klein, L.L.M.H. Habets, I.H.A. Aartman, J. Hoogstraten, C. van der Vleuten, U. van der Velden

Inleiding: De normering van Objective Structured Clinical Examinations (OSCE) is, zoals blijkt uit de literatuur, een discussiepunt tussen afdelingsdeskundigen en de werkvloer. Als de deskundigen een hoge norm per teststation stellen en voor alle stations een voldoende eisen, heeft dat hoge zakpercentages tot gevolg en aanpassing van de normen achteraf. Om een evidence based normeringmethode te kunnen kiezen werd een studie gedaan naar verschillende normeringmethoden met verschillende manieren van compenseren. Een van de onderzoeksdoelen is om het effect op het slagingspercentage te bestuderen van verschillende benaderingen van compenseren na een Borderline Regressie Normeringmethode voor een OSCE. Deze resultaten worden gevalideerd met een overall-beoordeling door seniordocenten in de onderwijspraktijk
Materiaal en Methode: $\mathrm{Na}$ een praktisch jaar in een onderwijspraktijk kregen 3e jaars tandheelkunde studenten een overall-beoordeling door seniordocenten op een 5-puntsschaal: excellent, goed, twijfelachtig, onvoldoende en slecht. Daarnaast werden de studenten $(n=127)$ beoordeeld d.m.v. een OSCE met 17 teststations uit 6 competentie domeinen/inhoudsgebieden. De studenten werden in 5-minuten teststations beoordeeld met een criteriumlijst 1-10 en onafhankelijk daarvan kreeg de student een globale beoordeling tijdens de OSCE op een 3- puntsschaal: geslaagd/ twijfelachtig/ gezakt. Voor de bepaling van de norm van de OSCE werd de Borderline Regressie Normeringmethode gebruikt: de scores 1-10 van elk OSCE teststation werden met lineaire regressie vergeleken met de 3-punts globale score. De norm voor de hele OSCE, gebaseerd op deze regressiequotiënten van de teststations, werd berekend met drie manieren van compenseren tussen teststations: de non-compensatie, totale compensatie en partiele compensatie: middelen binnen zes domeinen/inhoudsgebieden van competentie. Vervolgens werd het effect van deze drie manieren van compenseren op de het slagingspercentage voor de OSCE berekend.

Resultaten: Het resultaat van de klinische overallbeoordeling in de onderwijspraktijk door seniordocenten was Goed/excellent $75 \%$, Twijfelachtig $22 \%$ en Slecht/ onvoldoende $3 \%(n=110)$. In de groep van studenten 'goed/excellent' $(n=83)$, waren de slagingspercentages voor de OSCE: met non-compensatie benadering 6\%, partiele compensatie benadering $72 \%$ en totale compensatie benadering $92 \%$.

Conclusie/Implicaties voor de praktijk: Daar met de non-compensatie benadering slechts $6 \%$ van de goede/ excellente studenten zou slagen, lijkt deze benadering niet acceptabel. De overall-beoordeling van de seniordocenten lijkt milder dan blijkt uit elk van de compensatie benaderingen. Het dilemma is dat de overall-beoordeling van de seniordocenten geen gouden standaard is en daarom is nader onderzoek nodig. Samenvattend blijkt uit deze studie dat er weinig overeenstemming is tussen de drie compensatie benaderingen. De non-compensatie benadering moet verworpen worden, terwijl benaderingen met compensatie meer in overeenstemming met klinische beoordelingen lijken.

Correspondentieadres:

Meta E. Schoonheim-Klein, ACTA, Parodontologie, Louwesweg 1, 1066 EA Amsterdam, m.schoonheim@acta.nl.

De voorbeeldfunctie in de medisch specialistische opleiding

J.H. Stegeman, N.S. Klazinga 
Probleemstelling: Onderzoek naar de voorbeeldfunctie van opleiders maakt deel uit van een groter onderzoek. In het theoretische deel daarvan wordt beargumenteerd dat medische praktijkkennis ten principale niet volledig expliciteerbaar is. Overdragen van deze ' tacit knowledge' noopt tot gebruikmaking van een aanvullend instrumentarium: tonen en hardop denken. Medische specialisten hebben per definitie een voorbeeldfunctie, want aios moeten het vak voor een deel leren door 'af' kijken en 'af'luisteren.

Hier rapporteren we de resultaten van het empirische deel. Kijkend door de ogen van de aios staan twee vragen centraal:

1. hoe nemen aios in de heelkunde/kindergeneeskunde in het midden en aan het einde van de opleiding de voorbeeldfunctie waar?

2. wat valt daar didactisch over op te merken?

Methode: Er werden 22 semi-gestructureerde interviews gehouden met aios uit 2 regio's: 10 aios heelkunde; 12 aios kindergeneeskunde. Iedere aios werd tweemaal geïnterviewd (twee jaar interval). Gespreksthema: "hoe kijk je naar je opleiders?" Analysemethode: transcriptie; discourse analysis; codering met computerprogramma NVivo.

Resultaten: Opleiders strekken niet in toto tot voorbeeld. Specifieke kwaliteiten worden geobserveerd, gewaardeerd en naar eigen goeddunken nagevolgd. We onderscheiden: 'inspirerende modellen' 'negatieve modellen' 'functionele modellen'.

Alleen 'inspirerende modellen' noemen de aios zelf "mijn vóórbeeld". Ze zijn een minderheid. Bewonderde kwaliteiten worden nagevolgd, tenzij de aios menen dat het "beyond my possibilities" is.

AIOS heelkunde noemen meer vóórbeelden dan aios kindergeneeskunde.

'Negatieve modellen' worden vakmatig bekritiseerd of hen wordt "ongeïnteresseerdheid" in het vak of in opleiden verweten. $\mathrm{Zij}$ vormen ook een minderheid. Hun invloed lijkt beperkt: "als ik iets wil leren zoek ik het wel bij anderen". De meeste opleiders zijn 'functionele modellen'. Aios volgen elementen van de praktijkvoering na als ze die nuttig achten voor de eigen praktijkvoering: "je pikt van iedereen wel iets mee". In de heelkunde geldt het vooral operatietechnische vaardigheden; in de kindergeneeskunde communicatieve vaardigheden. De behoefte aan 'af'kijken en 'af'- luisteren van modellen is in het midden van de opleiding groter dan aan het einde: "vroeger keek je voortdurend hoe anderen het doen, nu heb ik mijn eigen manier wel gevonden". Echte vóórbeelden hebben dan ook iets van hun glans verloren. Opleiders die "lol hebben in opleiden", "uitleggen", "gestructureerd voordoen", "ordelijk van A naar B gaan", worden als betere opleiders beschouwd dan opleiders die zich simpelweg laten 'af'kijken en 'af'luisteren of 'chaotisch zijn'.

Conclusie: De voorbeeldfunctie is een gefragmenteerd en dynamisch verschijnsel. Opleiders die 'tonen' bewust voorzien van uitleg en toelichting -'tonen met ondertiteling' - en via 'hardop denken' hun 'denkroutes ontsluiten', maken de voorbeeldfunctie rijk en versterken daarmee model-leren.

Deze benadering valt grotendeels aan te leren. De didactische ontwikkeling ervan verdient nadere aandacht.

Correspondentieadres:

Drs. J.H. Stegeman, Zwethkade 30, 2641 SC Pijnacker,terpsteg@xs4all.nl.

Kenmerken van UMC's die een rol spelen bij integratie van sekse in de medische basiscurricula. Drie casestudies

\section{P. Verdonk, A.L.M. Lagro-Janssen}

Probleemstelling: Sekseverschillen bestaan in epidemiologie, presentatie, diagnostiek en behandeling en in betekenisgeving van ziekte. Een landelijk project om sekseverschillen in het medische onderwijs te integreren startte in april 2002 en is inmiddels afgerond. Welke kenmerken van de UMC's speelden een rol bij de integratie van sekse?

Methode/opzet: Het project kan worden beschreven als actieonderzoek en is in verschillende fasen uitgevoerd: (1) evaluatie van een Nijmeegs pilotproject; (2) inrichting van een digitaal kenniscentrum met onderwijsmateriaal (www.kenniscentrum SDMO.nl); (3) screening van studiegidsen naar de lacunes in seksespecifiek onderwijs alsmede mogelijkheden sekse in te voegen en gesprekken met onderwijsdirecteuren en trekkers; (4) screening van onderwijsmateriaal en het bespreken van aanbevelingen met onderwijscoördinatoren en; (5) evaluatie van het project met onderwijsdirecteuren en trekkers. Van alle bijeenkomsten zijn verslagen gemaakt en ter accordering voorgelegd. In dit onderzoek zijn gespreksverslagen alsmede transcripten van interviews in fase 5 geanalyseerd op kenmerken van UMC's die een rol speelden bij de integratie van sekse.

Resultaten/evaluatie: Aan de hand van drie case studies worden resultaten gepresenteerd. In het UMCA bleek veel weerstand tijdens twee groepsbijeenkomsten en ook was onder beleids-makers verdeeldheid over het project. De visitatieronde speelde een rol bij de acceptatie van het project door beleidsmakers en coördinatoren. Diverse seksespecifieke thema's werden niet geschikt bevonden vanwege de biomedische oriëntatie van het curriculum. 
In het UMCB kregen onderwijskundigen de integratie van sekse aan hun takenpakket toegevoegd. Communicatie naar de onderwijscoördinatoren was eenduidig en duidelijk en er bestond een duidelijke infrastructuur voor communicatie. Aanbevelingen zijn besproken met alle coördinatoren. Sekse is opgenomen in bestaande onderwijsevaluatieprocedures en de integratie van sekse en diversiteit is in het onderwijsbeleid opgenomen.

In het UMCC was aanvankelijk sprake van personeelswisselingen waardoor uitstel plaatsvond. Een zichtbare, enthousiaste trekker met korte lijnen naar de onderwijspraktijk speelde in het UMCC een doorslaggevende rol.

Conclusie/implicaties voor de praktijk: Kenmerken die een rol spelen zijn onder andere een goed georganiseerd en geoutilleerd onderwijsinstituut, procedures voor monitoring en evaluatie, en een heldere structuur voor communicatie met onderwijscoördinatoren en docenten. Draagvlak op beleidsniveau en een duidelijk uitgedragen standpunt zijn tevens van belang gebleken voor acceptatie van het project, evenals de aandacht van de visitatiecommissie voor integratie van sekse én voor cultuur. Een biomedische oriëntatie van de onderwijscoördinatoren in een $\mathrm{UMC} /$ faculteit alsmede een disciplinegewijs georganiseerd curriculum belemmerden de integratie van sekse. Duidelijk geventileerde weerstand door mensen met een hoge positie in het UMC/de faculteit vormde tevens een obstakel voor de verdere integratie van sekse. Enthousiaste trekkers die door de aard van hun werkzaamheden veel contact hadden met onderwijscoördinatoren en docenten faciliteerden de integratie van sekse.

Correspondentieadres:

Drs. P. Verdonk, UMC St Radboud, Vrouwenstudies Medische Wetenschappen, HAG 117, Postbus 9101, 6500 HBNijmegen,p.verdonk@hag.umcn.nl.

\section{Wetenschappelijke paper}

De invloed van toetsvorm (open- of gesloten-boek) op leerstrategie

M. Penninga, J.B.M. Kuks, J. Cohen-Schotanus (winnaar prijs wetenschappelijk paper)

Probleemstelling: Studenten verschillen in de manier waarop zij studeren. In de literatuur worden twee leerstrategieën regelmatig beschreven: diepgaand en oppervlakkig leren. De diepgaande leerstrategie lijkt beter aan te sluiten bij de doelen van het hoger onderwijs. Volgens het 3P-model van Biggs wordt het leren van studenten onder andere beïnvloed door de leeromgeving, waaronder de toetsvorm. In de literatuur wordt aangetoond (1) en wordt de verwachting uitgesproken (o.a. 2) dat openboek toetsen een diepgaande leerstrategie bevorderen. In dit onderzoek staat de relatie tussen toetsvorm en leerstrategie centraal. De vraagstelling luidt: leiden openboek toetsen tot diepgaander leren dan gesloten-boek toetsen?

Methode: Het onderzoek werd uitgevoerd bij Tweedejaars studenten Geneeskunde aan de Rijksuniversiteit Groningen $(\mathrm{N}=390)$. Deze studenten zijn gewend aan schriftelijke toetsen met een gesloten- en een open-boek gedeelte.Voorafgaand aan een dergelijke toets is deze studenten tweemaal de vragenlijst Diepgaande Leerstofverwerking (DLV) van Schouwenburg voorgelegd. Eenmaal werd het voorbereiden van het gesloten-boek gedeelte (GB) bevraagd en eenmaal het voorbereiden van het open-boek gedeelte (OB). Gekozen is voor een design waarbij de helft van de studenten startte met de vragenlijst over open-boek toetsen en de andere helft met de vragenlijst over geslotenboektoetsen.

De vragenlijst bestaat uit 24 items, welke op een vijfpuntsschaal moeten worden beantwoord $(1=$ nooit $5=$ altijd). De items zijn ondergebracht in drie subschalen: Kritisch Lezen (KL), Context Verbreden (CV) en Structuur Zoeken (SZ). Naast een score voor de subschalen wordt een totaalscore berekend.

Met behulp van een T-toets voor gepaarde waarnemingen is gekeken naar verschil in scores voor de subschalen en het totaal tussen het voorbereiden van gesloten-boek toetsen en het voorbereiden van openboek toetsen.

Resultaten: Studenten scoorden ten aanzien van het voorbereiden van gesloten-boek toetsen significant hoger voor de subschalen Context Verbreden (t $(371)=5.26, \mathrm{p}$ $<.001)$ en Structuur Zoeken ( $\mathrm{t}(377)=7.72, \mathrm{p}<.001)$ en voor de totaalscore $(\mathrm{t}(337)=5.38, \mathrm{p}<.001)$. Deze tendens is terug te zien in beide condities.

Conclusie: In tegenstelling tot de verwachting lijken gesloten-boek toetsen diepgaand leren meer te stimuleren dan open-boek toetsen. Een mogelijke verklaring is dat studenten bij de toets alles moeten kunnen reproduceren. Verder onderzoek naar de relatie tussen open-/geslotenboek toetsen, leerstrategie en resultaat is nodig.

Correspondentieadres:

Drs. M. Penninga, UMC Groningen, Onderwijsinstituut, A. Deusinglaan 1, 9713 AV Groningen, m.penninga@med.umcg.nl. 